\title{
Prince Albert Natural History Society
}

The BLUE JAY welcomes the news of the formation of another local natural history group this time at Prince Albert. The inaugural meeting was held on January 22, followed by the first executive meeting on February 22. Heading the group is Mr. Ed. W. Brooman, known as one of Prince Albert's most enthusiastic naturalists. He is president, Miss Grace Crooks is the secretary, and I. C. Collins is the treasurer. Other members of the executive are $R$. F. Arnold, Mrs. R. Mayson, Mrs. A. McKay, Mrs. Mary McIsaac, Barry Collins, J. Ross Homer and M. A. Welsh.

Plans have been made for monthly meetings from October to April, and field trips will be held during the spring and summer. The formation of this group, we hope, will be an incentive for others to follow. Each forms a link which will strengthen the solidarity of the Saskatchewan Natural History Society, and the BLUE JAY is sure to benefit, not only by new members, but by contributions relating to nature observations covering a much wider field.

\section{CONGRATULATIONS, PRINCE ALBERT!} SUCCESS TO YOUR SOCIETY!

\section{North American Co-operative Bird Migration Study-1954}

We hope most of our members will take part in this year's bird migration study - in co-operation with bird watchers, across the continent. In addition to first seen dates, make note of any heavy migration waves for the species involved. The species chosen are fairly common and easy to identify, so that everyone can take part. Please keep FIRST SEEN DATES for the following 31 species:

Canada Goose, Marsh Hawk, Killdeer, Mourning Dove, Nighthawk, Ruby-throated Hummingbird, Yellow-shafted Flicker, Eastern Kingbird, Eastern Phoebe, Barn Swallaw, Purple Martin, Am. Crow, House Wren, Catbird, Brown Thrasher, Redeyed Vireo, Black and White Warbler, Yellow Warbler, Myrtle Warbler, Ovenbird, Redstart, Red-winged Blackbird, Baltimore Oriole, Rosebreasted Grosbeak, Goldfinch, Slatecolored Junco, Chipping Sparrow, White-crowned Sparrow, Whitethroated Sparrow.

This is an excellent school project. Anyone taking part should obtain Taverner's "Birds of Canada," or, better, Peterson's "Field Guide to the Birds," so that all identifications may be accurate.

Send your list to Mr. Carmichael by June 15th or July 1st.

\section{Sask. N.H.S. Outing at Greenwater Lake}

A summer outdoor meeting of our Society will be held at Greenwater Lake Provincial Park, north of Kelvington, on Saturday and Sunday, June 13th and 14th. Groups will study the wildlife of the area, and on Saturday evening President Ralph Stueck will show some of his famous nature movies-in the dining hall, or outdoors "under the stars" if weather permits.

Camping space is available. There is a store and dining room. Hotel rooms are $\$ 2$ single, $\$ 2.50$ for two persons; light housekeeping cabins are $\$ 4$ and $\$ 5$ and accommodate four to six people. Dr. Stuart Houston is in charge of reservations, and those wishing to attend should write him at once, at Box 279, Yorkton, stating what accommodation is desired.

Bring your family to one of Saskatchewan's finest beauty spots and make our first summer outdoor meet a success.

Plan now to attend. 